\title{
Protestar, organizar y festejar. La resistencia obrera en Barrancabermeja y la huelga petrolera de 1977
}

Resumen: Este artículo describe y analiza la última gran huelga de los trabajadores petroleros en Barrancabermeja durante 1977, la represión de la que fue objeto, sus efectos en la cotidianidad de la ciudad y las consecuencias que tuvo para el movimiento obrero. La investigación parte de la hipótesis de que el conflicto reconfiguró la cotidianidad barranqueña como consecuencia de la represión oficial, ante la cual emergieron formas culturales de resistencia obrera expresadas mediante lo organizativo, lo festivo y lo burlesco. Una descripción analítica basada en periódicos, boletines y testimonios orales, interpretados a la luz de los estudios sobre la "cultura popular radical", el "campo de fuerza" y las "catástrofes".

Palabras clave: huelga, sindicalismo, fiesta, resistencia.

\section{Protest, organization and celebration. The Workers Resistance in Barrancabermeja and the 1977 oil strike}

Abstract: This article describes and analyses the last great strike of the oil workers in Barrancabermeja during 1977, the repression of the strike, its impact in the city, and the consequences it had for the labor movement. The investigation stems from the hypothesis that the conflict reconfigured the daily life of Barrancabermeja as a result of official repression, in which cultural forms of worker's resistance emerged and were expressed through the organizational, the festive, and the burlesque. This article offers an analytical description based on newspapers, bulletins, and oral testimonies interpreted in the light of studies of "popular radical culture", "force field" and "catastrophes".

Keywords: strike, trade unionism, festival, resistance.

\section{Protestar, organizar e festejar. A resistência operária em Barrancabermeja e a greve petroleira de 1977}

Resumo: Este artigo descreve e analisa a última grande greve dos petroleiros em Barrancabermeja, no ano de 1977, a repressão de que foram objeto, seus efeitos na vida diária da cidade e as consequências que trouxe para o movimento operário. A pesquisa parte da hipótese de que o conflito reconfigurou a cotidianidade de Barancabermeja como consequência da repressão oficial, perante a qual surgiram formas culturais de resistência operária expressadas através do organizativo, do festivo e do burlesco. Uma descrição analítica com base em jornais, boletins, e depoimentos orais, interpretados à luz dos estudos sobre a "cultura popular radical", o "campo de força" e as "catástrofes".

Palavras-chave: greve, sindicalismo, festa, resistência.

Cómo citar este artículo: Helwar Hernando Figueroa Salamanca y Daniel Orlando Ramírez Galvis, "Protestar, organizar y festejar. La resistencia obrera en Barrancabermeja y la huelga petrolera de 1977”, Trashumante. Revista Americana de Historia Socia/ 15 [2020]: 34-56.

DOI: 10.17533/udea.trahs.n15a02

Fecha de recepción: 2 de mayo de 2019

Fecha de aprobación: 24 de octubre de 2019

Helwar Hernando Figueroa Salamanca: Doctor en Estudios Latinoamericanos por la Universidad de Toulouse, Francia. Profesor Titular de la Universidad Industrial de Santander.

Correo electrónico: herlwarff@uis.edu.co

Daniel Orlando Ramírez Galvis: Estudiante de la maestría en Historia de la Universidad Nacional de Colombia. Correo electrónico: dramirezga@unal.edu.co 


\title{
Protestar, organizar y festejar. La resistencia obrera en Barrancabermeja y la huelga petrolera de $1977^{\star}$
}

\author{
Helwar Hernando Figueroa Salamanca y Daniel Orlando Ramírez Galvis
}

\section{Introducción}

En Barrancabermeja, la huelga de 1977 liderada por la Unión Sindical Obrera E(USO) representó en el imaginario de los obreros una guerra de gran intensidad, consecuencia de la militarización de la ciudad, las detenciones arbitrarias, las torturas y los allanamientos de los que fueron objeto los huelguistas. Esta represión fue leída como una suerte de catástrofe social, es decir, un conjunto de sucesos que "han creado siempre la posibilidad de un cambio radical en la vida cotidiana". $\mathrm{Y}$ al tenor de dichos acontecimientos los trabajadores recordaban que por esos años "nosotros teníamos que preparar la huelga como si fuera una guerra". ${ }^{2}$ Este testimonio revela el grado de intensidad de una acción social colectiva cargada de elementos culturales, políticos y organizacionales, interiorizados por los obreros como una especie de "guerra industrial". ${ }^{3}$ Las huelgas, sociológicamente hablando, comparten cualidades intrínsecas relacionadas con el mundo de lo laboral y de las relaciones sociales que allí se establecen. Es un fenómeno histórico y social que una vez formada la clase obrera colombiana adquiere cierta efectividad y modularidad, ${ }^{4}$ y que encuentra su germen en las nuevas relaciones sociales que

* Artículo de investigación derivado del proyecto "Barrancabermeja, una ciudad rebelde: La huelga de 1977 y la cultura obrera", escrito en el marco del Taller sobre el estudio del conflicto y los movimientos sociales en Colombia, adscrito al grupo de investigación Sagrado y Profano de la Universidad Industrial de Santander.

1. Ágnes Heller, Sociología de la vida cotidiana (Barcelona: Ediciones Península, 1987) 24.

2. Entrevista de Daniel Orlando Ramírez Galvis a entrevistado 1, Barrancabermeja, 15 de septiembre de 2015 .

3. Según John Womack, desde la Inglaterra decimonónica se decía que las huelgas ocupaban un lugar similar al de la guerra en las relaciones entre los países, ya que el miedo a la huelga generaba una interrupción tan grande a los negocios y al trabajo como lo hacía la guerra. John Womack, Posición estratégica y fuerza obrera. Hacia una nueva historia de los movimientos obreros (México: Fondo de Cultura Económica, 2007) 59.

4. Para Sidney Tarrow, "modularidad" es "la capacidad de una forma de acción colectiva para ser utilizada por una variedad de agentes sociales contra una gama de objetivos, ya sea por sí misma o 
instauró la modernidad capitalista a principios del siglo XX. Esta nueva clase apeló de manera regular a la huelga para denunciar sus pésimas condiciones de vida, la insalubridad de sus viviendas y la violación de los escasos derechos laborales que poseían. Una acción colectiva que desde entonces se acompaña con expresiones carnavalescas y festivas. La música, el baile y el discurso burlesco son rituales y prácticas culturales que les permiten a los barranqueños organizar y transformar su mundo en un contexto social marcado por las diferencias políticas, las desigualdades económicas y la diversidad cultural propias de la región.

La huelga petrolera de 1977 en Barrancabermeja debe ser entendida como un fenómeno social histórico de resistencia obrera, cuya festividad comunal transforma la cotidianidad de sus habitantes y ante la cual el Estado responde negativamente con acciones de fuerza. Era tal la forma en la que la huelga alteraba a la población que su efecto equivalía, según el sociólogo Alfredo Molano, al impacto generado por un aumento salarial de los trabajadores petroleros que repercutía significativamente en la economía del puerto. ${ }^{5}$

Se podría decir, recurriendo a la célebre metáfora de E. P. Thompson para comprender la sociedad inglesa del siglo XVIII (aquella de la corriente eléctrica que magnetizaba una placa que contenía unas limaduras de hierro), que durante la huelga laboral de 1977 se configuró un "campo de fuerza" en el que diversos grupos sociales brindaron su apoyo hacia un sector u otro, según correspondieran a sus intereses e "identidades de clase". ${ }^{6}$ En este sentido, es interesante observar cómo las identidades durante las huelgas se flexibilizan, pese a que cotidianamente pueden parecer homogéneas y estáticas. Hubo, por ejemplo, trabajadores petroleros que, aun como asalariados, brindaban apoyo logístico al bloque antihuelga, y, a su vez, sectores de las directivas de la Empresa Colombiana de Petróleos (Ecopetrol), ${ }^{7}$

en combinación con otras formas". Sidney Tarrow, El poder en movimiento. Los movimientos sociales, la acción colectiva y la política (Madrid: Alianza Editorial, 1997) 69.

5. Alfredo Molano, En medio del Magdalena Medio (Bogotá: Centro de Investigación y Educación Popular, 2009) 29.

6. Esta categoría nos será útil porque permite comprender la polarización de las relaciones de poder entre los dos bloques enfrentados durante la huelga: uno contrahegemónico (el bloque pro-huelga) y otro hegemónico (bloque antihuelga). Edward P. Thompson, Tradición, revuelta y consciencia de clase (Barcelona: Editorial Crítica, 1989) 40-41.

7. La mayoría de los testimonios recogidos revelan lo común que fue el hecho de que tanto supervisores como mandos medios, así como algunos directivos de Ecopetrol, le entregaran información importante al sindicato relacionada con las medidas que esta tomaría en contra de los obreros durante la huelga. Dicho fenómeno puede responder al hecho de que algunos mandos medios como los supervisores iniciaron laborando en la empresa como obreros; no obstante, por cuestiones de ascensos podían escalar algunos puestos en la jerarquía laboral de la empresa. Así, muchos supervisores terminaron facilitando información provechosa a los intereses del sindicato, por su identidad política y cultural afín al mundo de los obreros petroleros; aunque otros tenían una fuerte simpatía por las acciones de la fuerza pública en el contexto de la huelga. 
militantes de los partidos tradicionales (como el conservador) y sectores de la Iglesia católica que manifestaban su solidaridad con la huelga. ${ }^{8}$

Es importante insistir en que dicho conflicto es significativo por las repercusiones que tuvo para el movimiento petrolero y para la comunidad barranqueña al transformar su cotidianidad. Además, fue significativo por ser el movimiento huelguístico petrolero con mayor duración (67 días) en la historia de Barrancabermeja (la siguiente huelga fue la del 2004, es decir, 27 años después y con magnitudes más modestas); por pervivir en la memoria colectiva del movimiento obrero de la ciudad, y por haberse tratado de una protesta en la cual se empleó un variopinto repertorio de expresiones culturales: violencia simbólica, realización de asambleas clandestinas, publicación del Diario del paro, uso de las “oraciones", los rumores y la fiesta.

En consecuencia, se pretende descubrir los orígenes sociales y culturales de la huelga de 1977 en Barrancabermeja, explorar las estrategias organizativas de los trabajadores y examinar las formas culturales de resistencia. En conjunto, estos aspectos configuraron una cultura de protesta que resistió la violencia institucional, que transformó el diario vivir en la ciudad mediante el uso de novedosas pautas organizativas (lucha festiva), comunitarias y cívicas que históricamente han sido parte de la cultura popular radical barranqueña. ${ }^{9}$ Las principales fuentes con las que se construye el relato provienen de tres núcleos que analíticamente se interpelan y complementan entre sí. Por un lado, las entrevistas y el Diario del paro, ${ }^{10}$ los cuales revelan significativos detalles sobre la suerte de los obreros durante la huelga, en especial sobre las connotaciones festivas y burlescas de la protesta en momentos de agitación social. Por otro lado, los artículos de prensa y de revistas que mencionan

8. Durante los acontecimientos de la huelga, organizaciones políticas de izquierda como la Alianza Nacional Popular (ANAPO), el Movimiento de Izquierda Revolucionaria (MIR) y la Unión Nacional de Oposición (UNO), suscribieron una carta conjunta con otras organizaciones como el Directorio Municipal Conservador, en la que expresaban su apoyo a la huelga y le solicitaban al entonces presidente Alfonso López Michelsen el cambio del alcalde militar por los constantes abusos y excesos de la fuerza pública para con los manifestantes. "Los políticos: Piden el cambio del alcalde militar y respaldan la huelga de la USO", Vanguardia Liberal (Bucaramanga) 20 de septiembre de 1977. Para el caso del apoyo de la Iglesia católica, véase William E. Plata y Helwar H. Figueroa Salamanca, "Iglesia, resistencia pacífica y no violencia. La diócesis de Barrancabermeja, Colombia (1988-2005)”, Anuario de Historia Regional y de las Fronteras 22.1 (2017): 137-168.

9. Según Mauricio Archila, esta "cultura popular radical" se basaba en "el conjunto de valores, tradiciones y prácticas que cuestionaban elementos centrales del sistema de dominación imperante en la Colombia de los años 20 a 50", soportada, además, en aspectos como el nacionalismo, un anticlericalismo y una solidaridad de clase evidente entre los obreros. Mauricio Archila, Aquí nadie es forastero. Testimonios sobre la formación de una cultura radical: Barrancabermeja 1920-1950 (Bogotá: Centro de Investigaciones y Educación Popular, 1986) 110-111.

10. Esta fuente está compilada en el libro, cuyo nombre del compilador se supone es un seudónimo, Paul French, comp. " ¡No fue una huelga... fue una guerra...!”. Conflicto laboral en Ecopetrol 1977 (Bogotá: Mundo Gráfico Editores, 2003), que reúne documentos producidos durante el conflicto laboral tanto por obreros y Ecopetrol como por periódicos de orden nacional. Obra que será usada en extenso en el presente artículo. 
sucesos ausentes en otras fuentes, lo que permite reconstruir cronológicamente la huelga desde perspectivas que no coinciden directamente con la visión del mundo de los trabajadores.Y, por último, un conjunto de obras teóricas e historiográficas sobre las particularidades de la cultura del río, la cultura popular barranqueña y las condiciones sociales y económicas de Colombia (E. P. Thompson, Eric Hobsbawm, Mauricio Archila, Orlando Fals Borda, entre otros), que proveen los elementos necesarios para una interpretación integral del fenómeno estudiado.

\section{Barrancabermeja, una ciudad híbrida, festiva y de protesta}

La irrupción de la industria extranjera en Barrancabermeja durante el segundo decenio del siglo XX es, sin lugar a duda, el punto de quiebre de la historia de una región cuya cotidianidad y economía experimentó desde entonces un desarrollo acelerado y sin precedentes de las fuerzas productivas, de los medios de producción y de la división técnica y social del trabajo. El arribo de la Tropical Oil Company (conocida entre los obreros como Troco) inauguró una economía de nuevo cuño, la de enclave, previo exterminio de los escasos indígenas yariguíes y del despojo de las tierras de los colonos. Estas condiciones convirtieron aquel paupérrimo puerto sobre el río Magdalena en un "enclave petrolero" habitado por personas provenientes de todo el país, particularmente de Antioquia, la Costa Caribe, Boyacá y los Santanderes, y del extranjero. ${ }^{11}$

Esta posición estratégica de Barranca como "puerto petrolero" estimuló, además de los mencionados cambios en las relaciones sociales de producción, una mezcla interesante de costumbres, tradiciones y prácticas procedentes de diversos escenarios culturales: el ribereño proveniente de la Costa Caribe y del departamento de Bolívar — asociado a la pesca, a la agricultura y a los usos del agua, propios de una "cultura anfibia" - , ${ }^{12}$ cuyas gentes se caracterizaban por su festividad, su buen sentido del humor y su capacidad de asumir la vida con sosiego; ${ }^{13}$ el proveniente de la región andina, caracterizado por estar compuesto por personas retraídas y de modales serviles, acostumbradas a jornadas laborales prolongadas, y el traído por los emigrantes extranjeros, principalmente estadounidenses, que vivían aislados en sus casas lujosas detrás de los muros construidos por ellos y que buscaban recrear sus costumbres y hábitos. Dicha mezcla entre lo tradicional (movido por la influencia del río) y lo moderno (la industrialización) convirtió a Barranca

11. De hecho, fue tan importante el crecimiento de esta que para 1927 de los 12,000 habitantes, 200 eran estadounidenses y 5,000 trabajadores petroleros, cifra que determinará la posterior configuración urbana de la ciudad. Renán Vega y otros, Petróleo y protesta obrera. La USO y los trabajadores petroleros en Colombia (1923-2008), vol. 2 (Bogotá: Corporación Aury Sará Marrugo, 2009) 106.

12. Orlando Fals Borda, Historia doble de la Costa, t. 1 (Bogotá: Universidad Nacional de Colombia / Banco de la República / El Áncora Editores, 2002) 21B.

13. Fenómeno que el sociólogo Orlando Fals Borda denominó “complejo del dejao”. Este tiene que ver con tendencias de la gente costeña al descuido, a la informalidad, a la apatía y al incumplimiento. Comportamiento que no debe ser equiparado a una falta de conciencia, ya que este dejao "procede de una acción a otra por impulsos y actos inmediatos, no muy previsivos; pero eficaces a corto y a mediano plazo”. Fals Borda 158B-160B. 
en una especie de crisol cultural, que a la postre determinaría el surgimiento de una cultura rebelde y festiva, pero a la vez tremendamente excluyente y estigmatizada. En el imaginario regional, la capacidad rebelde unida a la "cultura de río", definida por Orlando Fals Borda, quien se basó en la propia autoimagen de sus habitantes, — análisis que sigue siendo pertinente a pesar de los cuestionamientos a su metodología y a su evidente compromiso político- crearon todas las condiciones para que la sociedad establecida continuase argumentando que Barranca es una ciudad diferente, extraña. ${ }^{14}$ Así esta imagen tenga un grado de subjetividad tanto para los barranqueños como para los otros, se ha convertido en una expresión de creación de sentido en medio de la guerra y de la exclusión, en un territorio que para sus pobladores todavía está en proceso de construcción. ${ }^{15}$

La "modernidad industrial" — entre otros dispositivos — instauró la disciplina fabril mediante la rigidez de los horarios y la supresión del "quehacer" campesino, en apariencia improvisado y mezclado con la vida cotidiana, pero indispensables para responder a las necesidades más apremiantes en los talleres y el campo. ${ }^{16}$ Así, la fiesta, el juego y el alcohol comienzan a ser controlados bajo el supuesto de ser contrarios a la productividad y a la "ética del trabajo". Racionalidad capitalista que transformó la cotidianidad local cuando la Troco levantó un muro de malla durante la década de 1920, con el ánimo de segregar espacialmente a Barranca en dos mitades: la "gringa", donde vivían los extranjeros y las directivas, con hospital, escuelas, bellas casas, acueducto y condiciones higiénicas favorables, inaccesible para los pobladores y las autoridades locales; ${ }^{17}$ y la "maldita", habitada por colonos pobres, afrodescendientes y los obreros de todos los colores y regiones, quienes moraban en campamentos y viviendas desprovistas de los más mínimos estándares sanitarios de salubridad y comodidad. ${ }^{18}$

14. Los críticos de los análisis de Fals Borda sobre la cultura costeña y del hombre de río, plasmados en la Historia doble de la Costa (2002), cuestionaron su metodología, centrada en el Investigación Acción Participativa (IAP), y su compromiso político que tiene por objeto contribuir a que los sectores populares sean conscientes de su capacidad liberadora. Para profundizar en este debate véase Charles Bergquist, "En nombre de la historia: una crítica disciplinaria de la Historia doble de la Costa de Orlando Fals Borda", Anuario Colombiano de Historia Social y de la Cultura 16-17 (1988-1989): 205-229; Jaime Andrés Otavo Gutiérrez, "De la sociología científica a la sociología crítica. ¿̨upturas o continuidades en la trayectoria intelectual de Orlando Fals Borda?" (Tesis de pregrado en Sociología, Pontificia Universidad Javeriana, 2010); Sylvia Juliana Riveros Torres, "Historia doble de la Costa: análisis de un clásico de la sociología colombiana" (Tesis de pregrado en Sociología, Pontificia Universidad Javeriana, 2012). Sin embargo, los aportes de Fals Borda en la compresión de esta región continúan construyendo un sentido de pertenencia en las comunidades que la habitan frente a los extraños, hasta el punto de que la cotidianidad de sus pobladores es un vivo reflejo de las categorías propuestas por Fals Borda hace ya más de cuarenta años.

15. Manuel Alonso, Conflicto armado y configuración regional. El caso del Magdalena Medio (Medellín: Universidad de Antioquia, 1997).

16. Edward P.Thompson, Costumbres en común (Barcelona: Crítica, 1995) 402.

17. Renán Vega, Gente muy rebelde. Enclaves, transportes y protestas obreras, vol. 1 (Bogotá: Ediciones Pensamiento Crítico, 2002) 129.

18. Jacques Aprile-Gniset, Génesis de Barrancabermeja (Bucaramanga: Instituto Universitario de la 
Esta segregación espacial estuvo acompañada, durante algunas décadas, de la construcción de una imagen excluyente y racista de la ciudad, que para algunos curas y sectores de la sociedad establecida colombiana era el hogar de la perdición y del comunismo. No en vano le fue atribuido a Barranca el calificativo degradante de ciudad de las tres P: putas, petróleo y plata. Un epíteto que les permitía a dichas élites combatir con recelo la tradición de protesta barranqueña y relacionar a su población con la insurgencia y el libertinaje, en un paisaje social donde históricamente han sido habituales los patrullajes de soldados y las alcaldías militares. Es probable que dicha militarización fuera la antesala de la posterior y violenta llegada de los grupos paramilitares en el segundo lustro de la década de 1980, quienes, so pretexto de combatir a las guerrillas, asesinaron y desterraron a importantes líderes sociales. ${ }^{19}$ La materialización de este nuevo dominio armado generó profundas transformaciones en la cotidianidad al fragmentar la permanente comunicación que mantenían los obreros con la comunidad, ${ }^{20}$ con la prohibición del ingreso de sindicalistas y líderes sociales a los barrios populares.

No resulta extraño, entonces, que la cotidianidad de Barrancabermeja haya estado marcada por el desarraigo y la desigualdad social; condiciones que, pese a generar profundas necesidades de orden económico, no impidieron que floreciera lo arrabalero y lo festivo. Fue común que desde 1930 un número de trabajadores petroleros y de pobladores ocupara su tiempo libre principalmente en la bebida, el juego, el baile y la prostitución, actividades realizadas frenéticamente al ritmo de valses, pasillos, guarachas, boleros y rancheras. ${ }^{21} \mathrm{~A}$ pesar del paso del tiempo, estos lugares y hábitos siguieron presentes en la cultura obrera durante los años setenta, década en la que se efectuó la famosa huelga.Y así lo revela un dirigente obrero

Paz, 1997) 192.

19. A pesar de que el centro de esta investigación es el movimiento obrero, resulta inevitable no hacer mención del peso que tiene en Barrancabermeja y en su área de influencia, el Magdalena Medio, la represión a los movimientos sociales y la violencia antisubversiva, la cual tuvo sus orígenes en el escenario de la Guerra Fría y en el establecimiento bipartidista del Frente Nacional (1957-1974), en la doctrina de la seguridad nacional, y en el Estatuto de Seguridad (1978-1982) que estableció, entre otras disposiciones, la continuidad de los alcaldes militares.Véase Francisco Leal Buitrago, La seguridad de la inseguridad. Colombia, 1958-2005 (Bogotá: Editorial Planeta, 2006); Renzo Ramírez y León Darío Marín, "Seguridad e ideología en Colombia, 1978-1982: análisis crítico del discurso de Julio Cesar Turbay Ayala”, Anuario de Historia Regional y de las Fronteras 20.2 (2015): 241-270. Una política antisubversiva que tuvo su máximo desarrollo en la década de 1980 con la creación de los paramilitares, que, por cierto, tuvieron sus orígenes en esta región. Carlos Medina Gallego, Autodefensas, paramilitares y narcotráfico en Colombia. Origen, desarrollo y consolidación: el caso "Puerto Boyacá" (Bogotá: Editorial Documentos Periodísticos, 1990); Mauricio Romero, Paramilitares y autodefensas, 1982-2003 (Bogotá: Editorial Planeta / Universidad Nacional de Colombia, 2003).

20. Álvaro Delgado, "El conflicto laboral en el Magdalena Medio", Conflictos, poderes e identidades en el Magdalena Medio, 1990-2001, comps. Mauricio Archila y otros (Bogotá: Centro de Investigación y Educación Popular, 2006) 133.

21. Amparo Murillo, coord., Un mundo que se mueve como el río. Historia regional del Magdalena Medio (Bogotá: Instituto Colombiano de Antropología / Colcultura / Plan Nacional de Rehabilitación, 1994) 54. 
cuando recuerda algunos turnos laborales que facilitaban este tipo de experiencias, como el "turno de la pernicia":

Que era el turno de 2:00 p.m. a 10:00 p.m. Usted salía del trabajo a las 10:00 p.m. y a veces todo el turno se iba para un bar a compartir en el bar y podía llegar a su casa en la madrugada y dormir toda la mañana, porque hasta las dos de la tarde volvía otra vez al trabajo. Solamente pocos trabajadores que no les gustaban los bares o estar con las prostitutas, estar metido en ese mundo, no iban.Y, a veces, entonces medio turno se encontraba, o tres cuartas partes del turno. Pero por lo general, los trabajadores de un turno se auto convocaban para ir de farra - fiesta- un día a un bar. Eso era como normal, porque su horario de trabajo lo facilitaba. ${ }^{22}$

Junto a esa cotidianidad festiva, construida con los elementos culturales regionales y foráneos, se configuró una tradición de protesta que durante décadas constituyó la mencionada cultura popular radical. Esta rebeldía determinó la beligerancia y la diversidad de la protesta, que coincidió en algunos momentos con la militancia política y sindical, ${ }^{23}$ y que derivó en la creación de organizaciones de corte liberal radical, socialista, anarquista y comunista (en todas sus vertientes). En estas particularidades hunde históricamente sus raíces el inicio del movimiento obrero petrolero y su expresión sindical, la USO, fundada clandestinamente en las inmediaciones de la quebrada La Putana en el año de 1923.

Desde luego, la tradición barranqueña de protesta ha comprometido a movimientos clásicos como el obrero y el campesino, y a los de más reciente data como el cívico, el de mujeres y el estudiantil. Estos sectores forjaron un variopinto repertorio de protesta social en el cual las huelgas, los paros cívicos y las acciones populares barriales adquirían un carácter tragicómico y carnavalesco que junto a la fiesta y el compañerismo transformaban la cotidianidad. Así ocurrió cuando durante la huelga y el paro cívico de 1963, "en medio de la represión, las noches se convirtieron en carnavales, donde las mujeres y los niños bailaban al son de cumbias", ${ }^{24}$ y así sucedió durante la huelga obrera de 1977, cuando los manifestantes hicieron uso de elementos organizativos, burlescos y festivos.

\section{Gestación de la huelga: organización y represión}

La huelga laboral de trabajadores petroleros comenzó el 25 de agosto de 1977, día de fiesta en la ciudad. A la sazón, se conmemoraba la reversión a la "concesión De Mares” que permitió en 1951 la nacionalización del petróleo colombiano y el

22. Entrevista a entrevistado 1.

23. Decía en una entrevista el líder social y abogado Diego Montaña Cuéllar que Barrancabermeja era totalmente diferente a la tradición liberal que había caracterizado al departamento de Santander, dado su talante antiimperialista, sindical y su identificación con las ideas de corte socialista. Alejo Vargas, Magdalena Medio santandereano. Colonización y conflicto armado (Bogotá: Centro de Investigación y Educación Popular, 1992) 50.

24. Vega y otros 264-265. 
fin del dominio extractivo de la Troco. Esta aparente coincidencia de fechas más que responder al azar simbolizó una estrategia política que buscó darle resonancia nacional a un conflicto obrero-patronal que desde la huelga de 1971 no adquiría dichas dimensiones.

El panorama económico y social del país en ese entonces era bastante desalentador. En efecto, durante la presidencia de Alfonso López Michelsen (1974-1978) se fomentó una serie de políticas económicas y laborales que favoreció a los empresarios a expensas del bienestar de los trabajadores ${ }^{25}$ quienes vieron cómo su situación empeoró con la alarmante inflación del casi 35\% que afectó ostensiblemente a la canasta básica familiar. ${ }^{26}$ No es de extrañar que dichas medidas estimularan la protesta social, tal como ocurrió desde 1975, año que marcó un hito al presenciar uno de los índices de movilización más elevados de la historia del país. ${ }^{27} \mathrm{Y}$ no debe sorprender que dicho escenario surtiera efectos en una Barranca cuya comunidad sufría, como lo recuerdan los entrevistados, la precariedad de los servicios públicos. Cuando el agua les llegaba a la casa, insalubre y llena de barro, ${ }^{28}$ la nula inversión en infraestructura, reflejada en la ausencia del alcantarillado y vías pavimentadas, y el profundo déficit de vivienda, que obligaba a la gente a vivir hacinada. Paradójicamente, este panorama social contrastaba con la riqueza generada por Ecopetrol, que en el departamento de Santander representaba el 50\% de su PIB.

A comienzos de 1977, los representantes de la USO iniciaron las conversaciones con Ecopetrol con el propósito de suscribir una nueva convención colectiva que rigiera por dos años las relaciones obrero-patronales para el buen funcionamiento de la empresa. Pese a los disensos entre las partes, dicha convención fue firmada y se decía que los obreros alcanzaron un aumento salarial de 1,500 pesos para el primer año y 1,700 pesos para el segundo, así como avances en materia de auxilios para vivienda, educación, prestaciones sociales, permisos sindicales y fondos rotatorios. ${ }^{29}$ Para sorpresa de los obreros, este acuerdo no iría más allá de la

25. Algunas de estas medidas fueron: promocionar el salario integral en contra de las prestaciones sociales de los trabajadores contempladas en el salario indirecto; fomentar una economía concertada condicionando los salarios de los trabajadores al aumento de su productividad; apoyar a los tribunales de arbitramento que resolvían, por lo general, los conflictos laborales a favor de los patronos, y prohibir el derecho a la huelga en aquellos sectores que el gobierno consideraba eran un servicio público.

26. Según Álvaro Delgado, si tomamos como referente el salario mínimo a principios de abril (1977) que rondaba los 2,340 pesos y lo ponemos en contraste con el valor de la canasta familiar que oscilaba la cifra de los 6,000 pesos, nos encontraremos con que la familia obrera experimentaba un déficit mensual de 3,660 pesos. Álvaro Delgado, Política y movimiento obrero 1970-1983 (Bogotá: Centro de Estudios e Investigaciones Sociales, 1984) 12-22.

27. Mauricio Archila, Idas y venidas, vueltas y revueltas. Protestas sociales en Colombia, 1958-1990 (Bogotá: Instituto Colombiano de Antropología e Historia / Centro de Investigación y Educación Popular, 2003) 195.

28. Entrevista de Daniel Orlando Ramírez Galvis a entrevistado 2, Bucaramanga, 28 de septiembre de 2015.

29. “Avance de obreros en Ecopetrol”, Voz Proletaria (Bogotá) 31 de marzo-6 de abril de 1977. 
sola firma, toda vez que el paso de los días les reveló la forma en la que Ecopetrol pasaba por alto apartes sustanciales.

En la víspera de la huelga, la USO expidió un comunicado a la opinión pública en el cual enunciaba los puntos de la convención que habían sido violados: ${ }^{30}$ contratistas, subcontratistas o intermediarios trabajaban en actividades propias de los trabajadores de Ecopetrol; desmejoras en la salud, debido al escaso personal médico (20 profesionales atendían en promedio 12,000 pacientes); la no congelación del precio de algunos alimentos vendidos por la petrolera a los obreros; la entrega del equipo National 130 de Ecopetrol a la Anson Drilling; la intención de imponer un nuevo escalafón sin la participación del sindicato; la violación a derechos sindicales al prohibir el ingreso de dirigentes obreros a centros laborales y condicionar ascensos y mejoras salariales a la desafiliación sindical, y la puesta en marcha de un plan para vender la planta de Policolsa a la Dow Chemical. ${ }^{31}$

Ante el desinterés de Ecopetrol por responder los memorandos presentados por la USO, los obreros efectuaron dos paros laborales los días 26 de julio y 5 de agosto, cada uno de una hora de duración. Su objetivo era el de ejercer presión para que cesaran las violaciones a la convención colectiva, sin plantearse que el conflicto desembocara en una huelga. De hecho, la huelga general fue el último recurso al que apelaron los trabajadores para defender sus derechos, ${ }^{32}$ ya que desde febrero de 1977 los obreros habían manifestado su intención de no realizarla:

La orientación de la empresa es la de hacernos ir a la huelga.Y la posición de los trabajadores es la de no lanzarnos a la huelga porque sí. Lo que pasa es que nosotros entendemos perfectamente que las pretensiones del gobierno y Ecopetrol son las de arrebatarnos nuestras conquistas y golpear nuestro sindicato. En esas condiciones nosotros iríamos a la huelga, pero ya obligados por la empresa y en defensa de nuestros derechos. Insisto: la única interesada en que haya huelga es la empresa. ${ }^{33}$

Finalmente, y ante los estériles llamados al diálogo, los obreros declararon la huelga el día 25 de agosto de 1977 en los distritos de producción de El Centro, Casabe, Cantagallo, Tibú y Cicuco, así como en la sede de refinación en Barrancabermeja. Una decisión legitimada por las declaraciones dadas el 5 de septiembre

30. "Causas del conflicto entre la USO y Ecopetrol”, “ ¡No fue una huelga... fue una guerra...!” 1-4; Diego Montaña Cuéllar, "La huelga y la crisis de Ecopetrol”, Alternativa (Bogotá) 3-10 de octubre de 1977: 11 .

31. En esta ocasión, el gobierno colombiano ofreció a través de Ecopetrol cuantiosos contratos por asociación a compañías extranjeras. "Ecopetrol insiste en reajuste de precios", El Tiempo (Bogotá) 29 de septiembre de 1977: 8A.

32. Según comentaba un obrero de entonces: "Los trabajadores colombianos [...] advierten que van a la huelga [...] y por lo general se lanzan a ella sólo cuando se agotan las fórmulas de una negociación aceptables. Los trabajadores no acostumbran a ir a la huelga caprichosamente; van a ella cuando la necesitan". Entrevista a entrevistado 1.

33. "Con la solidaridad, aseguramos el respeto a nuestras reivindicaciones", Voz Proletaria (Bogotá) 10-16 de febrero de 1977. 
por Ecopetrol, cuando aceptó que existieron incumplimientos a la convención y falencias en lo referente a la contratación y a la prestación de los servicios médi$\cos ^{34}$ Sin embargo, resultó desalentador para los obreros que, al poco tiempo de ser declarado el cese, el Ministerio de Trabajo suspendiera la personería jurídica de la USO, lo cual dejó en el orden de lo ilegal las acciones del sindicato, cuyos afiliados podían ser sancionados. Además, no satisfechos con esto, el gobierno nacional confirió a Ecopetrol facultades especiales para imponer sanciones a quienes participaran del cese laboral, lo cual fue aprovechado por esta cuando el 6 de septiembre despidió a los primeros 34 trabajadores. ${ }^{35}$

Simultáneamente, el gobierno nacional ordenó la militarización de la ciudad y de la refinería a través del despliegue de inteligencia militar ${ }^{36}$ y de aproximadamente 12,000 efectivos. Cifra importante si consideramos que el número de trabajadores que laboraban en la empresa ascendía a $8,000,{ }^{37}$ en una ciudad que entonces contaba con 120,000 habitantes. Esta toma del "puerto petrolero" representó el inicio de una fuerte arremetida del gobierno nacional con el objeto de controlar el proceso de extracción de crudo y producción de derivados en la mayor refinería del país, cuya alteración perjudicaba sustancialmente la dinámica de abastecimiento de combustible a nivel nacional. ${ }^{38}$

\section{Los comités de huelga}

El movimiento huelguístico optó por organizarse a través de una serie de comités. ${ }^{39}$ Estos se encargaron de asegurar la participación de los trabajadores en las actividades de agitación, propaganda y de protesta. Así como de materializar funciones análogas como mantener informada a la comunidad sobre los pormenores del conflicto, colaborar con aquellos obreros que tuvieran necesidades de orden económico, en común con otras organizaciones sociales, ${ }^{40}$ y sortear las dificultades

34. Temas y noticias. Boletín de la Empresa Colombiana de Petróleos, (Bogotá) 5 de septiembre de 1977, “ ¡No fue una huelga... fue una guerra...!”68-69.

35. Temas y Noticias, Boletín de la Empresa Colombiana de Petróleos, (Bogotá) 6 de septiembre de 1977, “¡No fue una huelga... fue una guerra...!” 77.

36. Tal como lo manifestaba la prensa: “La gente no se cuida tanto de los uniformados porque éstos se ven, sino de los civiles del Das, Defensa Civil, F-2, B-2, y soplones pagos por el Gobierno, atentos a sorprender conversaciones en favor de la USO o boletines del comité de Huelga" "En Barranca no temen a militares sino a los de civil", El Bogotano (Bogotá) 23 de septiembre de 1977, “¡No fue una huelga... fue una guerra...!”168.

37. Vega y otros 340 .

38. "Se acabó la gasolina extra y azul”, El Bogotano (Bogotá) 30 de agosto de 1977, “¡No fue una huelga... fue una guerra...!” 38.

39. Comité Nacional de Huelga y el Comité de Negociación, el Comité de Finanzas, el Comité de Salud, el Comité de Solidaridad, el Comité de Agitación y Propaganda, y los comités de sección o base.

40. El padre Eduardo Díaz recuerda que el entonces presidente de Ecopetrol, Juan Francisco Villarreal, les pedía a los sectores sociales que no intervinieran en la huelga. Entrevista de Daniel 
impuestas por la militarización de la ciudad que impedía a los huelguistas acceder a medicamentos y alimentación.

El Comité Nacional de Huelga y el Comité de Negociación, por ejemplo, estaban encargados de liderar las conversaciones con Ecopetrol y de emitir las directrices que debían seguir los obreros durante el cese laboral. Las disposiciones proveídas por dichos comités eran conocidas por los trabajadores a través del Diario del paro (elaborado en mimeógrafos repartidos estratégicamente en la ciudad), que fue el medio de comunicación predilecto de los obreros. Este diario representó una alternativa de comunicación, en medio de un panorama sumamente represivo en el cual portar un boletín informativo era castigado con cárcel, debido a que confrontó la información suministrada por boletines de Ecopetrol y de los periódicos nacionales que tildaban a la USO de subversiva. ${ }^{41}$

Con toda seguridad, un aspecto que facilitó tanto la divulgación del Diario del paro como la posibilidad de entregar alimentos y atención médica a los obreros y familiares fue la realización de reuniones clandestinas. Organizadas a tenor de la aparente seguridad que brindaban las viviendas de algunos obreros, debidamente vigiladas por los familiares (quienes avisaban las incursiones de la fuerza pública en el barrio), los obreros se reunían mediante comités con el propósito de asignar tareas y responsabilidades que les permitiera continuar con la huelga. En estas reuniones operaban los comités de base, que agrupaban a los obreros que laboraban en alguna dependencia o sección de la empresa, los cuales sintetizaban la esencia organizativa del movimiento obrero, cuya fortaleza residía en sus bases:

\footnotetext{
Son nuestros órganos de combate, cumplen su papel aglutinante y organizador, con ellos hemos dirigido toda nuestra propia lucha, con ellos todos y cada uno de nosotros hemos sido dirigentes, con ellos nos hemos vinculado a todas las tareas, en ellos hemos garantizado nuestra unidad, con ellos mantenemos comunicación de nuestro diario de paro. Los COMITÉS DE SECCIÓN han sido nuestra garantía del éxito. ${ }^{42}$
}

La importancia de dichos comités radicaba, principalmente, en que podían tener un control de los huelguistas y les permitía evadir la vigilancia de la fuerza pública que encontraba en la figura del esquirol un importante aliado. Este fenómeno, aunado a la vigilancia militar, constituyó, a grandes rasgos, el "teatro" de los sectores oficiales que respondió a la necesidad de violentar espacios de la

Orlando Ramírez Galvis a Eduardo Díaz, Barrancabermeja, 18 de septiembre de 2015.

41. "Sigue la represión en Barrancabermeja. Allanamientos y amenazas de muerte", El Bogotano (Bogotá) 6 de octubre de 1977, “¡No fue una huelga... fue una guerra...!” 232. Para citar otro caso: el día 27 de septiembre de 1977, bajo el titular "26 Millones ha invertido la USO en huelga de Barranca”, El Tiempo ponía en cuestión los recursos del sindicato, al insinuar que con este dinero se daba "participación económica a grupos alzados en armas". El Tiempo (Bogotá) 27 de septiembre de 1977.

42. Diario del paro (Barrancabermeja) 22 de octubre de 1977, “iNo fue una huelga... fue una guerra...!” 305 . 
intimidad, privar de ciertas libertades de movilidad y expresión, y extender la violencia hacia los familiares de los manifestantes y la comunidad en general. No obstante, los obreros y los sectores solidarios contrapusieron a dicho "teatro" un "contrateatro" compuesto por formas culturales de resistencia y manifestaciones de fraternidad. Esta solidaridad provino de sectores sociales del magisterio, de la Iglesia católica, ${ }^{43}$ del movimiento campesino, de sectores populares y sindicales y - aún más importante- del seno familiar, como sucedió con las esposas de algunos obreros, quienes se comprometieron con la huelga. ${ }^{44}$

Los obreros desarrollaron otras formas de protesta que iban más allá del usual componente organizativo, representado en los comités, y que tomaron matices comunitarios y burlescos. Tal como lo manifestaba un obrero, respecto a la solidaridad y la cotidianidad: "Precisamente era una de las formas de unión. Los sancochos, los partidos de fútbol o prácticas en las canchas. O sea, se transformaba no solamente (cotidianidad) sino que también se combinaba la unión de la gente, en la alegría de la gente para mantener vivo ese entusiasmo por lo que estaba luchando". ${ }^{45}$ Prácticas culturales que en el contexto del conflicto se transformaron en una "cultura de protesta", cuyo rasgo más significativo fue el de vivir la huelga como una fiesta. La alegría carnavalesca y la imaginación creativa al momento de protestar se superpuso a la escenografía de la violencia impuesta por el orden estatal. Rasgos que, en términos generales, se corresponden con el surgimiento de la huelga en el mundo occidental. ${ }^{46}$

Este tipo de situaciones eran registradas por los medios de comunicación cuando expresaban equívocamente que los pobladores se tomaban estas jornadas "deportivamente", lo cual quería decir con una supuesta espontaneidad y falta de

43. En la prensa del día 28 de agosto de 1977 se publicó una noticia en la que se hablaba de un comunicado divulgado en la ciudad en el que miembros del clero local apoyaban el paro de maestros de la Federación Colombiana de Educadores (FECODE), la cual por esas fechas iniciaba su actividad sindical en el país. En el mismo contexto, también fue evidente la solidaridad de la Iglesia católica para con la huelga de trabajadores petroleros, demostrado en el apoyo estratégico que algunos sacerdotes brindaron a los manifestantes. "Clero local publica apoyo a magisterio en paro”, Vanguardia Liberal (Bucaramanga) 28 de agosto de 1977.

44. Tal como lo manifiesta uno de los entrevistados "La señora de un trabajador de tubería o mecánica, si en su casa se daba la reunión y los veía fallengue (débil), y ella también estaba al día con el Diario del paro [...] entonces la tipa intervenía ahí y les daba fuerza o insultaba a los maridos porque no eran tan consecuentes como querían. Incluso, tenemos varias anécdotas donde las mujeres impidieron que sus maridos fueran esquiroles: les decían que se separaban, pero no iban a permitir eso. Fueron, en un momento determinado, como más consecuentes que sus maridos. Pocos casos, pero se dieron. Las mujeres salieron como más valerosas o tuvieron más pertenencia con el proceso de la huelga". Entrevista a entrevistado 1.

45. Entrevista de Daniel Orlando Ramírez Galvis a entrevistado 4, Barrancabermeja, 12 de septiembre de 2015 .

46. Hobsbawm manifestaba que: "el concepto de huelga y el de la fiesta no están separados claramente; los mineros 'juegan' cuando están en huelga, y los planes de los cartistas para una huelga general en 1839 eran planes para una fiesta nacional”. Eric Hobsbawm, Sobre la historia (Barcelona: Editorial Crítica, 1998) 216. 
conciencia. Es decir, se desconocía el carácter festivo de la protesta. Lo mismo ocurrió cuando la comunidad rechazó a la fuerza pública por intentar convencerlos de no participar en la huelga mediante el perifoneo de avisos y la reproducción de música popular o típica de la región (vallenatos, rancheras) en camiones repletos de militares ${ }^{47}$ quienes también malinterpretaron esta cultura muy ligada a la región costeña y su tendencia a la informalidad, al humor y a lo festivo. ${ }^{48}$

\section{Cultura burlesca y violencia simbólica}

Los obreros elaboraron escritos satíricos y delirantes cuando observaron que la vigilancia oficial y las acciones de los esquiroles estaban perjudicando la dinámica de la huelga. ${ }^{49}$ En estos se mencionaban los elementos más significativos de estos "patevacas", como eran llamados. Unas veces, esta suerte de cólera fue canalizada a través de oraciones que tomaban la estructura del tradicional del padrenuestro:

¡Oh señor! Tú que eres mi patrón / de rodillas te pido en mi oración / que te acuerdes de darme un aumentico $[\ldots] /$ i Por favor! / Y yo que estoy a punto de ser supervisor / Que cada temporal lo espero con temblor / ¡no me dejes baypasiado! Mi señor [...] / Ya mis espaldas están cansadas de aguantar / y mis manos de escribir / más no importa trabajar y palanquiar, / ¡con tal de verte sonreír! / ¡Oh patrón! Como te admiro, / cuando reprende a los demás / de rodillas yo te pido, / porque ya no aguanto más. El Plan setenta te regalo / El sirviente más fiel yo te seré / Pero déjame ser súper te lo ruego /Y feliz la pata estiraré / Por los siglos de los siglos, ¡Amén! ${ }^{50}$

Escrito donde el patrón representa a un todopoderoso y complaciente dios, que recibía plegarias de un débil, sumiso y suplicante esquirol. Algo similar hacían los

47. "Comunicados y música por parte del ejército”, Vanguardia Liberal (Bucaramanga) 17 de septiembre de 1977; Diario del paro (Barrancabermeja) 26 de septiembre de 1977, " ¡No fue una huelga... fue una guerra...!" 182.

48. Diría el sociólogo Javier Giraldo que en el "Paro" se presencia:"exaltación ritual de una violencia que denuncie significativamente la violencia institucionalizada". Javier Giraldo, "La reivindicación urbana", Controversia 138-139 (1987): 193.

49. Es dificil determinar y explicar en el presente artículo cada una de las causas que motivaron a los llamados "esquiroles" a actuar de dicha forma. No obstante, y de acuerdo con lo que ocurrió en la misma dinámica de la ciudad durante la huelga en la que sectores de comerciantes y de transportadores públicos apoyaban en cierto sentido el fin de la huelga y la no materialización del paro cívico de septiembre de 1977, podríamos decir que probablemente los esquiroles optaron por su posición debido a cuestiones económicas, en el sentido de que pudo haber un miedo subrepticio a ser despedidos de la empresa. Además, en el caso de mandos medios como los supervisores, por más simpatía que sintieran hacia las manifestaciones de los obreros de base no podían parar sus actividades debido a que por su no sindicalización eran directamente expulsados de la empresa. Aunque para lograr comprobar esta hipótesis se requiere acceder a fuentes primarias (entrevistas y documentos producidos por estos autores) que permitan comprobarlo, esto no fue posible en las pesquisas realizadas para esta investigación.

50. Frente Obrero. Boletín informativo de la Unión Sindical Obrera. Subdirectiva de Refinería (Barrancabermeja), “№ fue una huelga... fue una guerra...!” 20. 
obreros cuando dicho desdén fue reflejado en el uso de otros escritos que le atribuían a la usual figura del esquirol una serie de calificativos degradantes, relacionados con su supuesto conformismo, su mediocridad y por "carecer en absoluto de moral". Se decía que para ser esquirol era menester: "Un cepillo para que lo use con el gerente cuando éste lo solicite; un par de rodilleras para pedir ascensos; un par de tapones para los oídos, para no escuchar los consejos de sus compañeros consecuentes; y un trapero para lavar la casa del gerente, los días de descanso". ${ }^{51}$

El uso de lo ridículo también fue importante como forma de caricaturizar las figuras del orden de la ciudad, ya que la risa cumple un papel desmitificador, al erigirse como verdugo del miedo. Fue común ver a burros y a caballos deambulando por las calles de una Barranca dominada por los militares con letreros como "Yo soy Matallana", ${ }^{2}$ que hacían alusión al general José Matallana, comandante de varias operaciones militares en la ciudad; o "soy el alcalde de Barranca", en referencia al alcalde militar Álvaro Bonilla. Esta protesta simbólica cumplía de cierta forma lo sentenciado por Mijail Bajtin, cuando afirmaba que: "Los insultos ponen en evidencia el verdadero rostro del injuriado: lo despojan de sus adornos y de su máscara; los insultos y los golpes destronan al soberano",53 más aún cuando se usaban animales como el burro que simboliza docilidad y cierta estupidez. ${ }^{54}$

Por otro lado, como estaba en boga que algunos opositores de la huelga informaran vía telefónica a la fuerza pública el posible paradero de algún dirigente obrero o el lugar donde se efectuaban las reuniones (que generalmente terminaban en allanamientos), los obreros decidieron llamar al batallón para informar de la supuesta existencia de material subversivo en determinada casa. Cuando las tropas llegaban y asaltaban la vivienda se encontraban con que allí no vivían huelguistas, sino esquiroles. ${ }^{55}$

Esta deformación burlesca del conflicto (que no suponía incomprensión) libraba a los pobladores del terror que ocasionalmente imponían las figuras del orden político y militar. De ahí que se desarrollaran acciones callejeras como la "operación tachuela", que se llevaba a cabo con puntillas y grapas dejadas sobre las calles de la ciudad para frenar el avance de los camiones militares y buses que transportaban esquiroles; asimismo, se efectuaban acciones colectivas como la llamada "guerra de la pulga", que consistía en reuniones de grupos de cerca de treinta personas que "al grito de ¡viva la huelga de la USO!, o lanzando consignas contra el alcalde,

\section{Frente Obrero 20.}

52. "Fiesta popular por salida del Alcalde”, El Bogotano (Bogotá) 6 de octubre de 1977, “¡No fue una huelga... fue una guerra...!" 233.

53. Mijail Bajtin, La cultura popular en la Edad Media y en el Renacimiento. El contexto de François Rabelais (Madrid: Alianza Editorial, 2003) 178.

54. "El burro es uno de los símbolos más antiguos y vivos de los 'inferior' material y corporal, cargado al mismo tiempo de un sentido degradante (muerte) y regenerador". En este sentido es que ha sido usado el asno como "el símbolo bíblico de la humillación y la docilidad". Bajtin 75; 179.

55. "El Paro Cívico en Barranca... Hasta los soldados se rebelaron", Alternativa (Bogotá) 10-17 de octubre de 1977: 8-9. 
apedreaban los buses, retirándose en forma inmediata a otros sitios, cuando aparecía el ejército". ${ }^{56}$ Una mezcla entre lo burlesco y lo simbólico que estimuló un control social comunal que interpeló a la autoridad y al esquirol, quien simbolizó una figura similar al "sapo" y cuyo libreto ha desempeñado un papel importante en la violencia social del país. ${ }^{57}$

\section{Alternativas de comunicación: entre asambleas, rumores y disfraces}

Las asambleas estaban expresamente prohibidas, lo cual no impidió que los trabajadores se reunieran en los espacios acondicionados por los comités de base. Tal como lo menciona el sociólogo James Scott: "En el simbolismo político de la mayoría de las formas de dominación personal está contenido el presupuesto implícito de que los subordinados se reúnen sólo cuando reciben autorización de sus superiores. Por lo tanto, cualquier reunión no autorizada [...] se considera como una amenaza en potencia". ${ }^{58}$

En este sentido fueron representativas cuatro asambleas clandestinas realizadas en la huelga de 1977 y que engañaron la vigilancia oficial al efectuarse en lugares o circunstancias ajenas a la dinámica sindical. La primera se organizó en una parroquia durante el mes de octubre (el de mayor agitación durante la huelga) con el beneplácito del párroco Ignacio Rosero. ${ }^{59}$ Este cura abrió las puertas del templo a los obreros para que se rindieran los informes de las conversaciones adelantadas con el gobierno y la asamblea fue estratégicamente disuelta momentos antes del arribo de la fuerza pública. ${ }^{60}$

Otra de las asambleas fue efectuada en el cementerio principal, cuando se consumaba el entierro de un obrero que había fallecido en condiciones ajenas a la huelga. En esta también se rindieron informes, intervino un reconocido líder y se presentó un breve altercado con la fuerza pública:

Pues no había realmente ninguna despedida religiosa ni nada en la capilla, sino que, aprovechando esa circunstancia, el compañero Montaña Cuéllar se dirigía a los trabajadores. El ejército finalmente se dio cuenta de lo que estaba pasando, que era como una asamblea, y el ejército intervino dentro del cementerio. Se metían por las paredes, y se formó un berenjenal verraco. En

56. "Barranca: la guerra de la pulga”, Alternativa (Bogotá) 19-26 de septiembre de 1977, 10-11.

57. María Victoria Uribe, Antropología de la inhumanidad. Un ensayo interpretativo sobre el terror en Colombia (Bogotá: Norma, 2004) 51.

58. James Scott, Los dominados y el arte de la resistencia. Discursos ocultos (México: Ediciones Era, 2000) 88.

59. Cuando la policía trató de detener al padre Ignacio Rosero durante el paro cívico del año 1963 , entonces párroco del barrio Palmira, los pobladores reaccionaron en su defensa, con lo que provocaron una fuerte pedrea que dejó un número importante de heridos. "Récord de paro (II). Ni garrote, ni soluciones", Vanguardia Liberal (Bucaramanga) 7 de octubre de 1977.

60. Diego Montaña Cuéllar, “USO: derrotando el terror negro”, Alternativa (Bogotá) 17-24 de octubre de 1977: 25; Diario del paro (Barrancabermeja) 10 de octubre de 1977, “¡No fue una huelga... fue una guerra...!”250-251. 
el cementerio no hubo detenidos ni nada y logramos el fin que nosotros estamos buscando [...] que se les pudiera dar un informe directo a los trabajadores. ${ }^{61}$

Una tercera asamblea, convocada en las instalaciones del teatro Barrancabermeja, agrupó a un número importante de obreros, quienes se citaron, supuestamente, a disfrutar de un filme. La convocatoria a esta congregación fue tan efectiva que pasó desapercibida ante la siempre vigilante autoridad:

A través de la estructura que tenían, se les informó que fueran a cine.Y la gente fue al cine. Al teatro le cabían 1000 personas. Se puso a rodar la película y a mitad de película una comisión le dice al maquinista del teatro que le bajara el volumen. El tipo pataleó, pero se le obligó a bajar el volumen. La película sigue rodando, y se usa este espacio en el teatro para desarrollar allí una asamblea del sindicato en mitad de huelga. Terminadas las intervenciones, se le vuelve a poner el volumen a la película, y los líderes salieron antes de que terminara $[. .$.$] y el resto de trabajadores$ termina al final.Y ahí no hubo nada, ese fue un gol perfecto que le metimos nosotros al alcalde, que se preciaba de no permitir ninguna reunión en ninguna parte. ${ }^{62}$

Por último, hubo una cuarta asamblea efectuada en un colegio de la ciudad, donde obreros se entremezclaban con la comunidad educativa - a propósito del apoyo de algunos maestros - frente a la mirada de los militares, a quienes les fue imposible reconocer a los obreros y dirigentes que ingresaban al colegio al vestirse como estudiantes y al portar los elementos que los caracterizaba (morral, libros, folders, etcétera). ${ }^{63}$ Creatividad que es recordada por uno de los entrevistados: "Hubo mucha creatividad en que la gente cambiara su fisionomía. Hasta el extremo de que hubo compañeros que no los dejaban entrar a una reunión porque - se pensaba - no era de esa reunión. Hasta que les tocó quitarse su disfraz para que dijeran que él sí era". ${ }^{64}$

Esta serie de asambleas clandestinas fueron exitosas debido a que pobladores, comerciantes, educadores, entre otros, brindaron ayuda estratégica a los huelguistas; aunque también fue fundamental el empeño de los obreros por comunicar la hora y el lugar donde se iban a efectuar estos encuentros sin que fuera filtrada la información. Así lo reportaba la prensa a finales del mes de octubre, cuando manifestaba que: "Para poder informar a sus compañeros de los sitios y horas de reunión, los trabajadores encargados de esta tarea consiguieron carros de paletas y cajas de embolar, y salieron por las calles de Barranca a pregonar sus productos mientras en voz baja daban la información correspondiente". ${ }^{65}$ Otra muestra de

61. Entrevista a entrevistado 1.

62. Entrevista a entrevistado 1.

63. "La huelga de la USO. A mayor presión, mayor firmeza", Alternativa (Bogotá) 31 de octubre - 7 de noviembre de 1977: 10.

64. Entrevista a entrevistado 1.

65. "La huelga de la USO" 10. 
la efectividad de estas estrategias de protesta que contribuyeron a que mucha información susceptible de ser dada a través del órgano informativo de los obreros Diario del paro, pero que corría el riesgo de ser filtrada a inteligencia militar (ya sea por el decomiso del material o la detención de quien lo repartía), fuese brindada de manera directa para evadir ese riesgo. Sin embargo, había momentos en que ni las asambleas ni los camuflajes ni el elemento burlesco permitían que la comunidad conociera situaciones adversas al movimiento. En este sentido, los rumores representarían una alternativa importante. Estos rumores denunciaban la represión, de manera especial cuando no se tenía noticia de algunos sindicalistas desaparecidos, y estimulaban el interés de la opinión pública por saber el paradero de dichos dirigentes. Así sucedió cuando al ser retenidos forzosamente Joaquín Orrego de la USO y Edilberto Cabrera de Fedepetrol emergieron los rumores sobre su posible secuestro y asesinato a manos de la fuerza pública. ${ }^{66}$ Sindicalistas que, ante las presiones sociales, fueron liberados por los militares tiempo después.

Tal como lo manifiesta el historiador Jean Delumeau, los rumores han servido en algunos momentos para detonar la cólera popular, y evidencian las "inquietudes acumuladas y [...] una preparación mental creada por la convergencia de varias amenazas o de diversas desgracias que suman sus efectos". ${ }^{67}$ Es decir, estos rumores eran más que simples correrías, ya que en cierto modo desnudaba a la violencia.

Es innegable que la resistencia obrera y su contrateatro lograron mitigar los efectos de la violencia institucional al frenar parte del control militar, gracias a la organización, al uso de formas culturales de protesta, al compromiso de las bases obreras y a la solidaridad de la comunidad. Sin embargo, dicho conflicto se prolongó pese a la mediación de congresistas y autoridades nacionales, y a los acercamientos entre representantes obreros y directivos de Ecopetrol. De hecho, la ausencia de un consenso postergó el final de un conflicto que pudo ser solucionado con más diálogo que represión, y que derivó en el tardío levantamiento del cese laboral el sábado 29 de octubre de 1977, tras 67 días de protesta.

El final de la huelga, tal como convinieron los obreros reunidos a través de sus comités de base (dado que el alcalde no permitió una asamblea para levantar la huelga, aun cuando había sido autorizada por el presidente), no significó para estos ni el fin del conflicto ni una paz laboral, sino un repliegue temporal para reorganizar nuevamente sus bases, sorprendidas por el alto grado de violencia desplegada en la ciudad. Pese a haber surgido como respuesta a ciertas necesidades, el conflicto generó otra serie de problemáticas no resueltas al aumentar las demandas ya existentes: libertad para los aproximadamente mil manifestantes que fueron retenidos en cárceles, ${ }^{68}$ el reintegro de los 217 obreros que habían sido despedidos y la devolución de la personería jurídica sindical, entre otras. Una situación que encontró

66. "Falsa versión sobre líder...", Vanguardia Liberal (Bucaramanga) 27 de agosto de 1977;“"Desmienten secuestro...", Vanguardia Liberal (Bucaramanga) 20 de octubre de 1977.

67. Jean Delumeau, El miedo en Occidente (Madrid:Taurus, 2012) 63.

68. "Pendientes reivindicaciones al cesar la huelga petrolera", Voz Proletaria (Bogotá) 3-9 de noviembre de 1977. 
su cenit en un atentado con granada contra un bus que transportaba trabajadores no huelguistas y que dejó como resultado un trabajador muerto y varios heridos.

En medio de estas adversidades, los barranqueños siguieron apelando al uso de lo festivo y lo burlesco cuando algunos manifestantes quemaban figuras que representaban al alcalde militar, ${ }^{69}$ y cuando se disponían a realizar un baile cívico con motivo de la renuncia de este, quien abandonaba su cargo ante el repudio de la comunidad. ${ }^{70}$ De igual modo, los obreros consiguieron que el Estado devolviera al sindicato su personería jurídica y considerara la libertad de los detenidos, presionaron a la empresa para que discutiera el reintegro del personal despedido, y alcanzaron significativas reivindicaciones:

Ecopetrol se ha visto obligada a reconocer públicamente las violaciones a la Convención Colectiva de Trabajo y a comprometerse a no seguir violando; ha empleado a personal médico, enganchado a término indefinido a trabajadores temporales, agilizado la construcción de ZONA HOSPITALARIA, ha incrementado el valor de las tiqueteras y frenado la firma del Contrato para entregar la Planta de Polietileno a la Dow Chemical. ${ }^{71}$

Estos logros pueden ser vistos como importantes victorias, ya que en medio de la intransigencia de Ecopetrol hubo una mejora parcial en el bienestar obrero y en la industria nacional. No obstante, una serie de reveses impidieron que muchas reivindicaciones se mantuvieran. ${ }^{72}$ Los trabajadores tras cada nueva convención firmada tuvieron que defender permanentemente los beneficios, otrora logrados a través de sucesivos paros parciales. Y, de hecho, no fue sino hasta el año 2004 cuando los obreros realizaron una nueva huelga, con terribles consecuencias para la industria nacional y la sindicalización laboral, debido a la venta del 20\% de Ecopetrol a particulares y un número elevado de obreros despedidos. ${ }^{73}$

\section{Conclusión}

Los obreros petroleros se rebelaron y decidieron ir a huelga en 1977, principalmente, porque su vida laboral y cotidiana se estaba volviendo insoportable. A grandes rasgos, podría argüirse que dicho inconformismo respondió al no cumplimiento de Ecopetrol a lo pactado en la convención colectiva de trabajo y a las condiciones económicas experimentadas. No obstante, el fuerte despliegue militar y la inusitada actitud del Estado de no fungir como garante del susodicho conflicto desencadenó una serie de enfrentamientos entre las partes, que bien pudieron

69. "Retorna el malestar a Barranca", Vanguardia Liberal (Bucaramanga) 14 de octubre de 1977.

70. "Fiesta popular" 233.

71. "Comunicado del Comité Nacional de Huelga”, 29 de octubre de 1977, “¡No fue una huelga... fue una guerra...!” 341.

72. Así lo demuestra la entrega en 1980 del equipo de perforación National 130 a una multinacional, que fue defendido en la huelga analizada.Vega y otros 354.

73. Vega y otros 433 . 
haber sido evitados con una efectiva concertación, lo que a la postre hubiera significado evitar una "catástrofe". Se podría decir que el cerco militar agudizó el hambre en la ciudad, la violencia institucional reafirmó la histórica posición estatal en estos conflictos laborales y la actitud de los empresarios reveló profundas contradicciones en el seno de las relaciones laborales de la industria petrolera. Esto explica la constante necesidad de los manifestantes de hacer uso de formas culturales de protesta, y de acudir a elementos de lo que otrora representó aquella cultura popular radical.

Es imposible negar la intrínseca relación entre la predominante cultura ribereña y festiva de los pobladores barranqueños con las formas culturales de resistencia usadas por los obreros para combatir las figuras del orden y la autoridad. Para cualquier observador, el uso de rumores, de escritos delirantes o de carteles burlescos puede resultarle una forma trivial de protestar; sin embargo, si se toma en cuenta la profunda militarización de la vida cotidiana, estas acciones fungieron como alternativas transformadoras sin las cuales pudo haber sido fragmentada la convivencia de la ciudad. Por esto, la idiosincrasia barranqueña siempre festiva y, en cierta medida, rebelde fue la base de la susodicha cultura de protesta. Además, podríamos decir, sin lugar a equívocos, que la cercanía de los obreros con la comunidad les proveyó un apoyo fundamental sin el cual hubiera sido impensable una resistencia tan larga. No obstante, la fuerza de los obreros provenía de sus bases, las cuales eran el motor que mantenía encendida la marcha de la huelga.

Bien podría decirse que las conquistas laborales y políticas de los obreros fueron alcanzadas a costa de un magno sacrificio, mediante las mencionadas formas organizativas y culturales de resistencia que encontraron su contraparte en los sectores sociales que consideraban poco justificadas las aspiraciones obreras. Tanto obreros como empresa-Estado sabían lo que representaba una huelga; empero, este último sector no contaba con el compromiso de los trabajadores y la solidaridad que despertó su causa en la ciudad, ni los obreros esperaban que la violencia institucional fuera a ser tan desmedida. En efecto, esta resistencia cultural de los trabajadores sirvió como elemento sorpresa, toda vez que las autoridades acostumbraban a esperar unas "acciones establecidas" de los obreros que, según Tarrow, "no son sólo lo que hace la gente cuando entra en conflicto con otros; es lo que sabe hacer y lo que los otros esperan que haga". ${ }^{74}$ En consecuencia, la fuerza pública esperaba la realización de mítines, marchas, concentraciones públicas, la toma a las instalaciones de la refinería, entre otras acciones; pero quizá no contaba con las reuniones clandestinas, el uso de lo risible y festivo, y la apelación a la máscara y al disfraz. Esto era, en efecto, muestra del contrateatro de los trabajadores, quienes con estas prácticas trataban de organizar ese mundo caótico que imponían los sectores dominantes sobre Barranca. De hecho, este campo de fuerza fue tan cautivante que, sin lugar a titubeos, podría decirse que la huelga — pese a no tener la fuerza que puede generar una revolución - transformó la cotidianidad barranqueña.

74. Tarrow 66. 


\section{Fuentes}

\section{Impresas}

French, Paul. Comp. “№ fue una huelga... fue una guerra...!”. Conflicto laboral en Ecopetrol 1977. Bogotá: Mundo Gráfico Editores, 2003.

\section{Orales}

Díaz, Eduardo, entrevista realizada por Daniel Orlando Ramírez Galvis. Barrancabermeja, 18 de septiembre de 2015.

Entrevistado 1, entrevista realizada por Daniel Orlando Ramírez Galvis. Barrancabermeja, 15 de septiembre de 2015.

Entrevistado 2, entrevista realizada por Daniel Orlando Ramírez Galvis. Bucaramanga, 28 de septiembre de 2015.

Entrevistado 4, entrevista realizada por Daniel Orlando Ramírez Galvis. Barrancabermeja, 12 de septiembre de 2015.

\section{Periódicos y revistas}

Voz Proletaria (Bogotá) 1977.

El Tiempo (Bogotá) 1977.

Vanguardia Liberal (Bucaramanga) 1977.

Alternativa (Bogotá) 1977.

\section{Bibliografía}

Aprile-Gniset, Jacques. Génesis de Barrancabermeja. Bucaramanga: Instituto Universitario de la Paz, 1997.

Archila, Mauricio. Idas y venidas, vueltas y revueltas. Protestas sociales en Colombia, 1958-1990. Bogotá: Instituto Colombiano de Antropología e Historia / Centro de Investigación y Educación Popular, 2003. . Aquí nadie es forastero. Testimonios sobre la formación de una cultura radical: Barrancabermeja 1920-1950. Bogotá: Centro de Investigaciones y Educación Popular, 1986.

Bajtin, Mijail. La cultura popular en la Edad Media y en el Renacimiento. El contexto de François Rabelais. Madrid: Alianza Editorial, 2003.

Bergquist, Charles. "En nombre de la historia: una crítica disciplinaria de la $\mathrm{Hi}$ storia doble de la Costa de Orlando Fals Borda”. Anuario Colombiano de Historia Social y de la Cultura 16-17 (1988-1989): 205-229.

Delgado, Álvaro. "El conflicto laboral en el Magdalena Medio". Conflictos, poderes e identidades en el Magdalena Medio, 1990-2001. Comps. Mauricio Archila 
y otros. Bogotá: Centro de Investigación y Educación Popular, 2006.

Política y movimiento obrero 1970-1983. Bogotá: Centro de Estudios e Investigaciones Sociales, 1984.

Delumeau, Jean. El miedo en Occidente. Madrid:Taurus, 2012.

Fals Borda, Orlando. Historia doble de la Costa. Tomo I. Bogotá: Universidad Nacional de Colombia / Banco de la República / El Áncora Editores, 2002.

Giraldo, Javier. “La reivindicación urbana”. Controversia 138-139 (1987).

Heller, Ágnes. Sociología de la vida cotidiana. Barcelona: Ediciones Península, 1987.

Hobsbawm, Eric. Sobre la historia. Barcelona: Editorial Crítica, 1998.

Leal Buitrago, Francisco. La seguridad de la inseguridad. Colombia, 1958-2005. Bogotá: Editorial Planeta, 2006.

Medina Gallego, Carlos. Autodefensas, paramilitares y narcotráfico en Colombia. Origen, desarrollo y consolidación: el caso "Puerto Boyacá". Bogotá:Editorial Documentos Periodísticos, 1990.

Molano, Alfredo. En medio del Magdalena Medio. Bogotá: Centro de Investigación y Educación Popular, 2009.

Murillo, Amparo. Coord. Un mundo que se mueve como el río. Historia regional del Magdalena Medio. Bogotá: Instituto Colombiano de Antropología / Colcultura / Plan Nacional de Rehabilitación, 1994.

Otavo Gutiérrez, Jaime Andrés. "De la sociología científica a la sociología crítica. ¿Rupturas o continuidades en la trayectoria intelectual de Orlando Fals Borda?’. Tesis de pregrado en Sociología, Pontificia Universidad Javeriana, 2010.

Plata, William E. y Helwar H. Figueroa. “Iglesia, resistencia pacífica y no violencia. La diócesis de Barrancabermeja, Colombia (1988-2005)". Anuario de Historia Regional y de las Fronteras 22.1 (2017): 137-168.

Ramírez, Renzo y León Darío Marín. “Seguridad e ideología en Colombia,19781982: análisis crítico del discurso de Julio Cesar Turbay Ayala”. Anuario de Historia Regional y de las Fronteras 20.2 (2015): 241-270.

Riveros Torres, Sylvia Juliana. "Historia doble de la Costa: análisis de un clásico de la sociología colombiana”. Tesis de pregrado en Sociología, Pontificia Universidad Javeriana, 2012.

Romero, Mauricio. Paramilitares y autodefensas, 1982-2003. Bogotá: Editorial Planeta / Universidad Nacional de Colombia, 2003.

Scott, James. Los dominados y el arte de la resistencia. Discursos ocultos. México: Ediciones Era, 2000.

Tarrow, Sidney. El poder en movimiento. Los movimientos sociales, la acción colectiva y la política. Madrid: Alianza Editorial, 1997.

Thompson, Edward P. Costumbres en común. Barcelona: Crítica, 1995.

. Tradición, revuelta y consciencia de clase. Barcelona: Editorial Crítica, 1989.

Uribe, María Victoria. Antropología de la inhumanidad. Un ensayo interpretativo sobre el terror en Colombia. Bogotá: Norma, 2004.

Vargas, Alejo. Magdalena Medio santandereano. Colonización y conflicto armado. Bogotá: 
Centro de Investigación y Educación Popular, 1992.

Vega, Renán. Gente muy rebelde. Enclaves, transportes y protestas obreras. Volumen 1. Bogotá: Ediciones Pensamiento Crítico, 2002.

Vega, Renán y otros. Petróleo y protesta obrera. La USO y los trabajadores petroleros en Colombia (1923-2008). Volumen 2. Bogotá: Corporación Aury Sará Marrugo, 2009.

Womack, John. Posición estratégica y fuerza obrera. Hacia una nueva historia de los movimientos obreros. México: Fondo de Cultura Económica, 2007. 